\title{
A Survey of Freshwater Mussels in the West Pearl River, Mississippi and Louisiana, 1995
}

by Andrew C. Miller, Barry S. Payne

Approved For Public Release; Distribution Is Unlimited 
The contents of this report are not to be used for advertising, publication, or promotional purposes. Citation of trade names does not constitute an official endorsement or approval of the use of such commercial products.

The findings of this report are not to be construed as an official Department of the Army position, unless so designated by other authorized documents. 


\section{A Survey of Freshwater Mussels in the West Pearl River, Mississippi and Louisiana, 1995}

by Andrew C. Miller, Barry S. Payne

U.S. Army Corps of Engineers

Waterways Experiment Station

3909 Hallls Ferry Road

Vicksburg, MS 39180-6199

Final report

Approved for public release; distribution is unlimited 


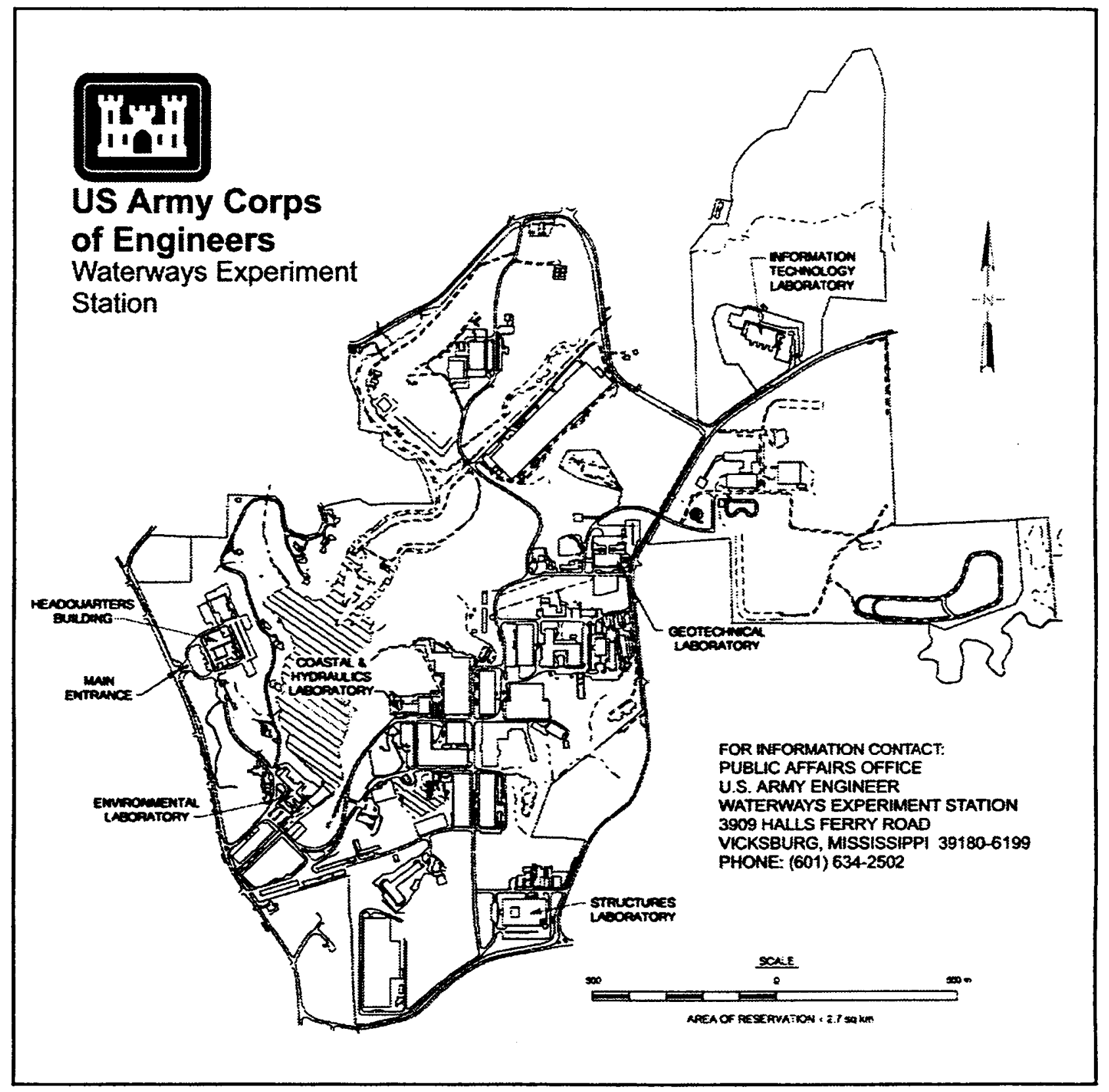

Waterways Experiment Station Cataloging-in-Publication Data

Miller, Andrew C.

A survey of freshwater mussels in the West Pearl River, Mississippi and Louisiana, 1995

/ by Andrew C. Miller, Barry S. Payne; prepared for U.S. Army Engineer District, Vicksburg. 34 p. : ill. ; $28 \mathrm{~cm}$. -- (Technical report ; EL-97-21)

Includes bibliographic references.

1. Freshwater mussels -- Pearl River (Miss. and La.) -- Geographical distribution. 2. Unionidae -- Pearl River (Miss. and La.) - Geographical distribution. III. Freshwater mussels -- Pearl River (Miss. and La.) -- Counting. 4. Unionidae - Pearl River (Miss. and La.) -Counting. I. Payne, Barry S. II. United States. Army. Corps of Engineers. Vicksburg District. III. U.S. Army Engineer Waterways Experiment Station. IV. Environmental Laboratory (U.S. Army Engineer Waterways Experiment Station) V. Title. VI. Series: Technical report (U.S. Army Engineer Waterways Experiment Station); EL-97-21.

TA7 W34 no.EL-97-21 


\section{Contents}

Preface $\ldots \ldots \ldots \ldots \ldots \ldots \ldots \ldots \ldots \ldots$

Conversion Factors, Non-SI to SI Units of Measurement . . . . . . . vii

1 -Introduction $\ldots \ldots \ldots \ldots \ldots \ldots \ldots \ldots \ldots \ldots \ldots \ldots \ldots \ldots \ldots$

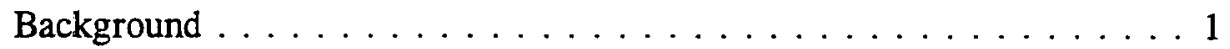

Purpose and Scope . . . . . . . . . . . . . . . 2

2-Study Area and Methods $\ldots \ldots \ldots \ldots \ldots \ldots \ldots \ldots \ldots$

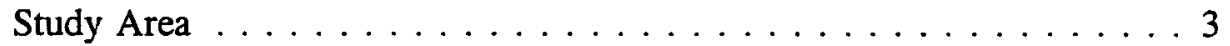

Methods . . . . . . . . . . . . . . . . . 6

3 -Bivalve Community $\ldots \ldots \ldots \ldots \ldots$

Characterization of Bivalve Community . . . . . . . . . 8

Description of Bivalves in Each River Reach . . . . . . . . . 8

Size Demography of Dominant Mussels . . . . . . . . . . . 13

Potamilus inflatus . . . . . . . . . . . . . . . . . . 14

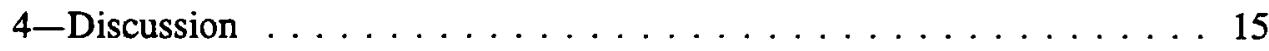

Bivalve Community $\ldots \ldots \ldots \ldots \ldots \ldots \ldots \ldots$

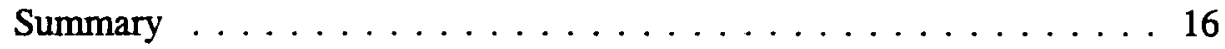

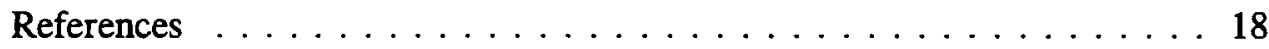

Appendix A: Summary of Qualitative Data Collected for West Pearl

River Project, $1995 \ldots \ldots \ldots \ldots$. . . . . . . . . . . . A1

SF 298 


\section{List of Tables}

Table 1. Site Numbers, Type and Number of Samples Collected, and Site Description for Mussel Collections for West Pearl River Project, Mississippi and Louisiana, 1995 . . . . . . . . . 5

Table 2. Freshwater Bivalves Collected Using Qualitative and Quantitative Methods for West Pearl River Project, 1995 . . . . . . . 9

Table 3. Percent Species Abundance and Percent Occurrence of Freshwater Bivalves Collected Using Qualitative Methods for West Pearl River Project, August 1995 10

Table 4. Percent Abundance of Mussel Species Collected Using Quantitative Methods in Bogue Chitto River Immediately Downriver of Lateral Cutoff, West Pearl River Project, 1995.

Table 5. Percent Occurrence of Mussel Species Collected Using Quantitative Methods in Bogue Chitto River Immediately Downriver of the Pearl River Canal, West Pearl River Project, 1995 . . . . . . . . . . . . . . . . . . . . . . . . . . 12 


\section{Preface}

A survey to assess community characteristics, density, population demography of dominant species, and the presence of rare or endangered species of mussels (Family: Unionidae) was conducted in the Pearl River near Slidell, LA. Work was done for the U.S. Army Engineer District, Vicksburg, and results will be used to assess environmental effects of maintenance dredging for resumption of commercial navigation traffic. Studies were conducted by the U.S. Army Engineer Waterways Experiment Station (WES) in AugustOctober 1995.

This report was prepared by Drs. Andrew C. Miller and Barry S. Payne, Aquatic Ecology Branch (AEB), Ecological Research Division (ERD), Environmental Laboratory (EL), WES.

Divers for the study were Messrs. Larry Neill, Robert T. James, Robert Warden, and Johnny Buchanan, Tennessee Valley Authority (TVA). Assistance in the field was provided by Mr. David Morrow, Ms. Nancy Atwood, Mr. David Armistead, and Mr. Steven George, WES. Mr. Gary Young, U.S. Army Engineer District, Vicksburg, assisted with the design of the survey and provided maps and other background information. Figures were prepared by Ms. Geralline Wilkerson, Jackson State University. Airboats and selected field gear were provided by TVA.

During the conduct of this study Dr. John Harrison was Director, EL; Dr. Conrad J. Kirby was Chief, ERD; and Dr. Alfred F. Cofrancesco was Chief, AEB.

At the time of publication of this report, Director of WES was Dr. Robert W. Whalin. 
This report should be cited as follows:

Miller, A. C., and Payne, B. S. (1997). "A survey of freshwater mussels in the West Pearl River, Mississippi and Louisiana, 1995," Technical Report EL-97-21, U.S. Army Engineer Waterways Experiment Station, Vicksburg, MS.

The contents of this report are not to be used for advertising, publication. or promotional purposes. Cilation of trade names does nol constitule an official endorsement or approval of the use of such commercial products. 


\section{Conversion Factors, Non-SI to SI Units of Measurement}

Non-SI units of measurement used in this report can be converted to SI units as follows:

\begin{tabular}{|l|l|l|}
\hline Multiply & By & To Obtain \\
\hline \hline feet & 0.3048 & meters \\
\hline miles (U.S. nautical) & 1.852 & kilometers \\
\hline
\end{tabular}




\section{Introduction}

\section{Background}

\section{Project description}

The U.S. Army Engineer District, Vicksburg, is studying plans for resumption of maintenance dredging on the West Pearl River, Louisiana and Mississippi. The project area lies within Washington and St. Tammany parishes, Louisiana, and Pearl River County, Mississippi. Approximately 5 miles of a 52-mile ${ }^{1}$ reach between the mouth of the Pearl River and River Mile (RM) 52.2 of the Pearl River will be affected. Dredged material would also be disposed of over the Pools Bluff and Bogue Chitto sills into the Pearl and Bogue Chitto rivers.

This project was authorized in 1935 , and construction was completed in 1956. However, in the early 1970s commerce on the West Pearl River declined significantly, and in 1975 the project was placed in limited operational status. This project would require dredging and snagging to allow dependable, year-round passage of commercial vessels.

Results of recent surveys by personnel of the U.S. Army Engineer Waterways Experiment Station indicated that extensive beds of freshwater mussels exist in the project area (Miller and Payne, in preparation). In addition, the project area is within the range of the threatened inflated heelsplitter mussel, Potamilus inflatus (U.S. Fish and Wildlife Service (USFWS) 1994). Personnel of the Vicksburg District requested that a mussel survey be conducted so that direct and indirect impacts of proposed channel work on mussels could be assessed. The primary objective was to search for $P$. inflatus

\section{Freshwater mussels}

Freshwater mussels (family: Unionidae) dominate the benthic biomass of stable gravel shoals in medium-sized to large rivers in the central United

1 A table of factors for converting non-SI units of measurement to SI units is presented on page vii. 
States. They are virtually nonmotile, live 20 or more years, and feed by filtering particulate organic matter from the water. Eggs are brooded in the gills, and immature mussels once released from the female spend a brief period on the fins or gills of a host fish (Coker 1919; Fuller 1974). Before the advent of plastics, shells were used in the button industry; today they are used to culture pearls (Sweaney and Latendresse 1982; Sitwell 1985). Once large-river species reach adult size, their thick shells make them invulnerable to most predators. Regardless of their ability to tolerate some natural and man-made disturbances, many species are considered to be imperiled (See Williams et al. 1993). Since the late 1970s, Unionidae have received considerable legislative protection from local, State, and Federal agencies (USFWS 1994).

Freshwater mussels are usually found where water velocities vary from 0.5 to $1.5 \mathrm{ft} / \mathrm{sec}$. Occasionally, thin-shelled mussels such as the paper pondshell, Utterbackia imbecillis, or the thick-shelled threeridge, Amblema p. plicata, reach densities of 200-300 individuals/square meter in water flowing less than $0.5 \mathrm{ft} / \mathrm{sec}$. However, in most mussel beds, total unionid density ranges from 20 to 50 individuals/square meter.

\section{Purpose and Scope}

The purpose of this study was to search for common, uncommon, and the threatened mussel Potamilus inflatus in the project area, and to analyze the effects of maintenance dredging on the mussels. The project area extends from the mouth of the West Pearl River to RM 52.2 on the Pearl River. 


\section{Study Area and Methods}

\section{Study Area}

The project area includes the southern tip of Mississippi and an eastem section of Louisiana (Figure 1, Table 1). Sample sites were on the West Pearl River, the lateral canal, and the Bogue Chitto River (Figure 1, Table 1). Mussels were collected in the following reaches.

\section{Upper Pearl River between Pools Bluff Sill and O. A. Green Port (Sites 14, 15, 16)}

Substratum in this reach consisted mainly of sand, silt, and gravel. Banks were steep and the shore was covered with flood-tolerant trees and shrubs. During the sampling period, water velocity was less than $0.5 \mathrm{ft} / \mathrm{sec}$.

\section{Bogue Chitto River}

Qualitative searches for mussels were made at Site 12 in the mouth of the Bogue Chitto River (Figure 1). Searches were also made in the lateral canal near the sill that regulates flow into the lower Bogue Chitto River (Site 13). Substratum at these two sites consisted mainly of sand, silt, and gravel. Quantitative and qualitative samples were taken in the Bogue Chitto River immediately downriver of the sill at the lateral canal. Substratum consisted of well-washed sand and gravel. Water velocity at the time of sampling was approximately $1.0 \mathrm{ft} / \mathrm{sec}$.

Thirty quantitative samples for mussels were taken in the upper Bogue Chitto River along the right descending bank and approximately $100 \mathrm{~m}$ from the lateral canal. Substratum consisted of sand, gravel, and shells, with little or no mud or organic matter.

\section{Lateral canal (Sites 42-45)}

Substratum in this reach consisted mainly of sand, silt, and gravel. During the time of the survey, water velocity was less than $0.5 \mathrm{ft} / \mathrm{sec}$. 


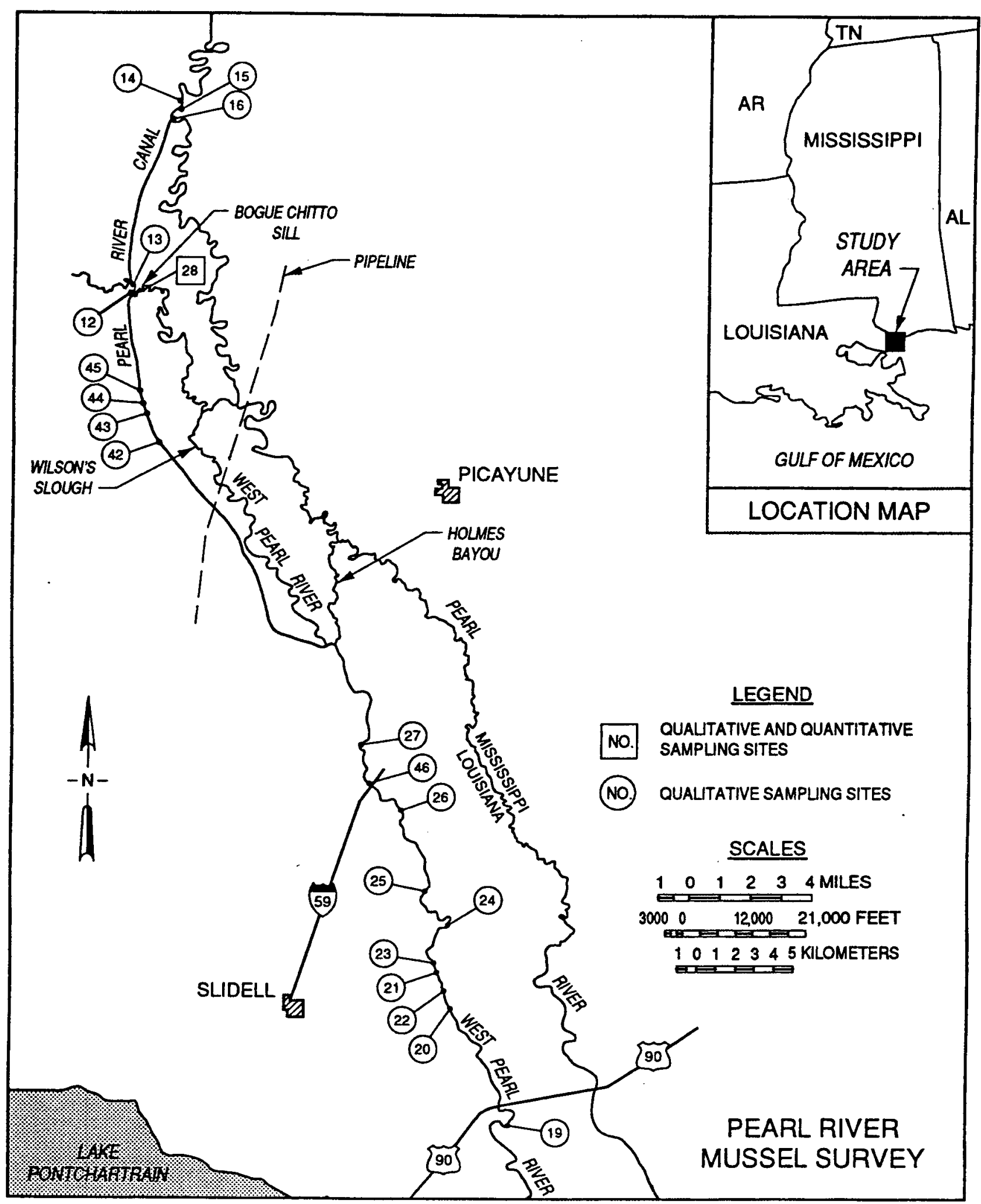

Figure 1. Sites surveyed for mussels using quantitative and qualitative methods in West Pearl River, 1995 (see Table 1) 


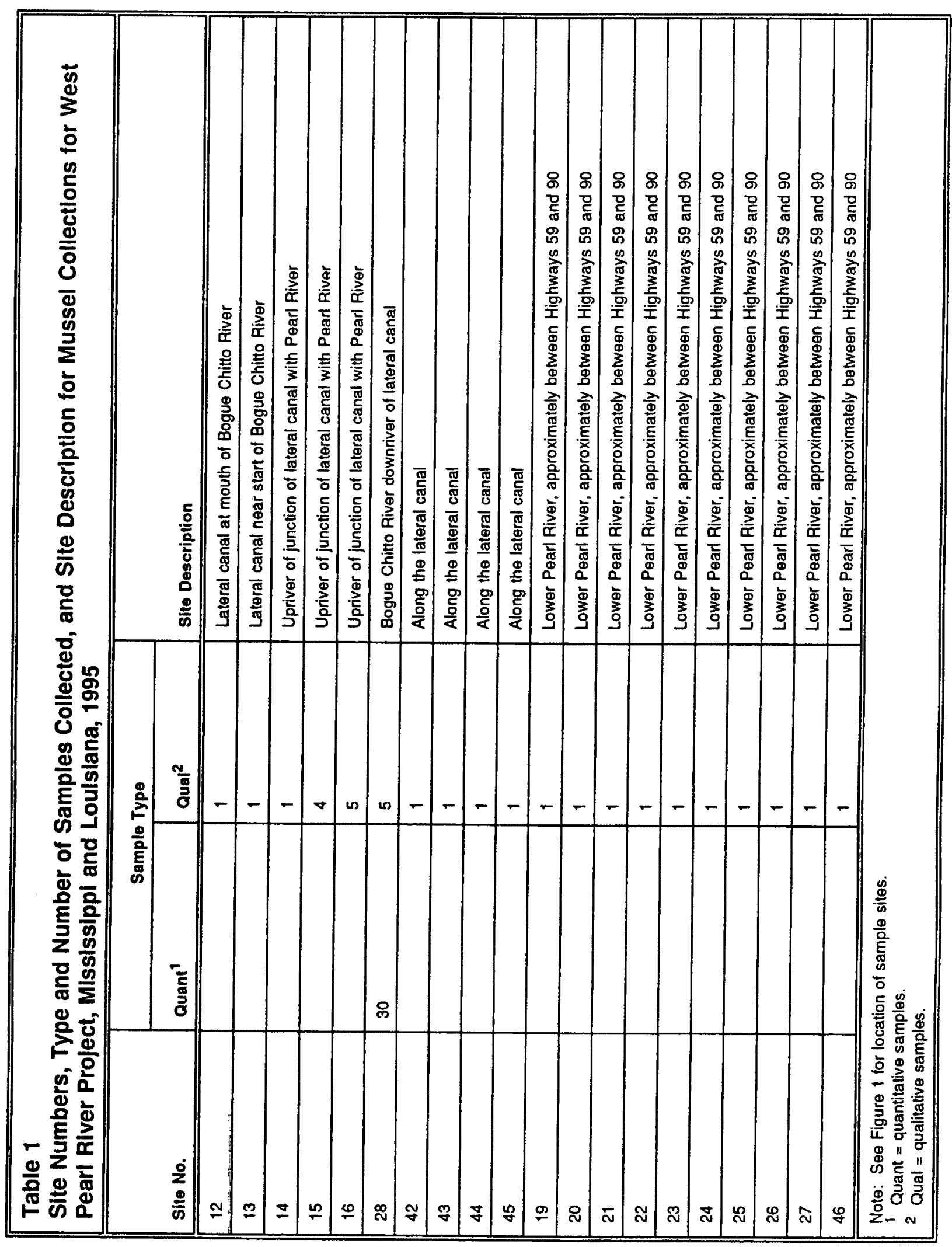


Lower Pearl River from just upriver of Highway 59 downriver to just below the Highway 90 Bridge (Sites 19-27, 46)

Substratum consisted of hard packed sand, silt, and mud. During the time of the survey, water velocity was less than $0.5 \mathrm{ft} / \mathrm{sec}$.

This is the second of two mussel surveys of the Pearl River for the Vicksburg District. In the previous survey, conducted at approximately the same time, quantitative and qualitative samples were collected in the Pearl River, Holmes Bayou, Wilson Slough, and the West Pearl River near Picayune, MS. A listing of sample sites, appropriate maps, and results of that survey can be found in Miller and Payne, in preparation.

\section{Methods}

\section{Preliminary reconnaissance}

A preliminary reconnaissance of the study area (mouth of the West Pearl River to RM 52.2 on the West Pearl River) was conducted prior to initiating intensive sampling. This was accomplished by two individuals who traversed the area in a small boat and inspected the shore and shallow water for live mussels and dead shells. They obtained information on substratum conditions, water velocity, and presence of instream cover. Field notes were recorded and sites suitable for detailed study were marked on topographic maps. Sites with a high likelihood of containing mussels were usually depositional areas, or immediately upriver of natural constrictions. Some low-density areas were searched to provide information to characterize the project area.

Qualitative and quantitative sampling was accomplished by divers in water deeper than $1 \mathrm{~m}$ and waders in shallow water. Divers and waders used the same collecting methods.

\section{Qualitative mussel samples}

Each collector placed a specific number of live mussels in nylon bags; usually 5 to 20. Collections were made without bias toward size or type. Workers attempted to exclude the Asiatic clam, Corbicula fluminea. If this species was inadvertently collected, it was later eliminated. The total time spent searching was recorded so that the number of mussels collected per minute was determined.

Special attention was directed toward locating live specimens or shells of the threatened heelsplitter mussel, $P$. inflatus. An intensive search for this species was made at or near exposed sand and gravel bars between Highways 59 and 90 (Figure 1). 
All mussels were brought to the surface, counted, and identified. Data were recorded on standard data sheets and returned to the laboratory for analysis and plotting. Shells of voucher specimens for each species were placed in plastic zipper lock bags and labeled with high rag content paper. Mussels not needed for voucher were returned to the river. Methods for sampling mussels were based on techniques described in Miller and Nelson (1983); Isom and Gooch (1986); Kovalak, Dennis, and Bates (1986); Miller and Payne (1988); and Miller et al. (1993). Mussel identification was based on taxonomic keys and descriptive information in Murray and Leonard (1962), Parmalee (1967), Starrett (1971), and Burch (1975). Taxonomy was consistent with Williams et al. (1992).

\section{Quantitative mussel samples}

In addition to qualitative methods, quantitative samples (that included unionids as well as $C$. fluminea) were taken at Site 28 in the Bogue Chitto River (Figure 1). At this site, ten 0.25 -sq $\mathrm{m}$ quadrats were obtained at each of three closely spaced subsites. All sand, gravel, shells, and live bivalves to a depth of $10-15 \mathrm{~cm}$ were excavated. Material was sent to the surface in a $20-\ell$ bucket and transported to shore. Sediment was washed through a series of three screens. All live mussels (including $C$. fluminea) removed from samples were placed in 4- $\ell$ zipper lock bags. Each bivalve was then identified and total shell length (SL) measured to the nearest $0.1 \mathrm{~mm}$ with digital calipers. Mussels identified and measured in the field were returned to the river unharmed.

\section{Analysis of mussel data}

Species diversity was determined with the following formula:

$$
H^{\prime}=-p_{j} \log p_{j}
$$

where $p_{j}$ is the proportion of the population that is of the $\mathrm{j}^{\text {th }}$ species (Shannon and Weaver 1949). Evenness was calculated with the modified Hill's ratio (Ludwig and Reynolds 1988). All calculations were done with programs written in BASIC or SAS (Statistical Analytical System) with a personal computer. 


\section{Bivalve Community}

\section{Characterization of Bivalve Community}

Twenty-two species of bivalves, including the nonindigenous $C$. fluminea, were collected in the project area using quantitative and qualitative methods (Table 2). The nonindigenous zebra mussel, $D$. polymorpha, introduced into the Great Lakes in the late 1980 s, was not found. Live $P$. inflatus, listed as threatened (USFWS 1994), was not found in the project area during this survey. Shells of this species were collected in the West Pearl River immediately upriver of the junction of Holmes Bayou (Miller and Payne, in preparation). Two fresh-dead specimens were found in July 1995 in the West Pearl River, St Tammany Parish (George, Dickerson, and Reine 1996).

The bivalve community in the project area can be characterized as species rich and diverse; typically, no single species dominated (Table 3). Based on qualitative collections, the most abundant species was Quadrula refulgens, which comprised 25 percent of the fauna and was found in 70 percent of all samples. The second most abundant species was Potamilus purpuratus, which comprised 16.7 percent of the fauna and was found in 74 percent of the samples. Eleven species each comprised 1-10 percent of the fauna, and nine species were less than 1 percent of the collection. Most mollusc species had thick or moderately thick shells; thin-shelled species such as Pyganodon grandis and Leptodea fragilis were uncommon in the project area.

\section{Description of Bivalves in Each River Reach}

\section{Qualitative Collections from Upper Pearl River between Pools Bluff Sill and O. A. Green Port (Sites 14, 15, 16) and Bogue Chitto River (Sites 12 and 13)}

Twelve species of mussels were collected at these sites. Collecting rate for all sites was low; overall, only 1.2 mussels were collected per minute. There was no single dominant species in this collection; four species, $P$. purpuratus, $Q u a d r u l a$ apiculata, Obliquaria reflexa, and $Q$. refulgens, each comprised approximately 20 percent of the fauna. In this river reach, Sites 14-16 had the 


\begin{tabular}{|c|c|c|}
\hline \multicolumn{3}{|c|}{$\begin{array}{l}\text { Table } 2 \\
\text { Freshwater Bivalves Collected Using Qualitative and Quanti- } \\
\text { tative Methods for West Pearl River Project, } 1995\end{array}$} \\
\hline Species & Qualitative & Quantitative \\
\hline Anodonta suborbiculata Say & $x$ & $x$ \\
\hline Corbicula fluminea (Muller) & $x$ & $x$ \\
\hline Elliptio crassidens (Lamarck) & $x$ & $x$ \\
\hline Fusconaia ebena (I. Lea) & $x$ & $x$ \\
\hline Fusconaia cerina (Conrad) & $x$ & $x$ \\
\hline Glebula rotundata (Lamarck) & $x$ & $x$ \\
\hline Lampsilis claibomensis (Lea) & $x$ & $\mathrm{x}$ \\
\hline Lampsilis omata (Conrad) & $x$ & $x$ \\
\hline Lampsilis teres (Rafinesque) & $x$ & $x$ \\
\hline Leptodea fragilis (Rafinesque) & $x$ & $x$ \\
\hline Megalonaias nervosa (Rafinesque) & $x$ & $x$ \\
\hline Obliquaria reflexa (Rafinesque) & $x$ & $x$ \\
\hline Plectomerus dombeyanus (Valenciennes) & $x$ & $x$ \\
\hline Potamilus alatus (Say) & $x$ & $x$ \\
\hline Potamilus pupuratus (Lamarck) & $x$ & $x$ \\
\hline Pyganodon grandis (Say) & $x$ & $x$ \\
\hline Quadrula apiculata (Say) & $x$ & $x$ \\
\hline Quadrula quadrula (Rafinesque) & $x$ & $x$ \\
\hline Quadrula refulgens (1. Lea) & $x$ & $x$ \\
\hline Toxolasma texasensis (1. Lea) & $x$ & $x$ \\
\hline Tritogonia vernucosa (Rafinesque) & $x$ & $x$ \\
\hline Truncilla donaciformis (I. Lea) & $x$ & $x$ \\
\hline Villosa lienosa (Conrad) & $x$ & $x$ \\
\hline Total species & 23 & 23 \\
\hline
\end{tabular}

greatest numbers of mussels; collection rate ranged from 0.8 to 7.4 individuals/ minute. Collecting rate at Site 12 in the lateral canal near the Bogue Chitto River was 0.8 mussels/minute. In the mouth of the Bogue Chitto River, no mussels were collected. 


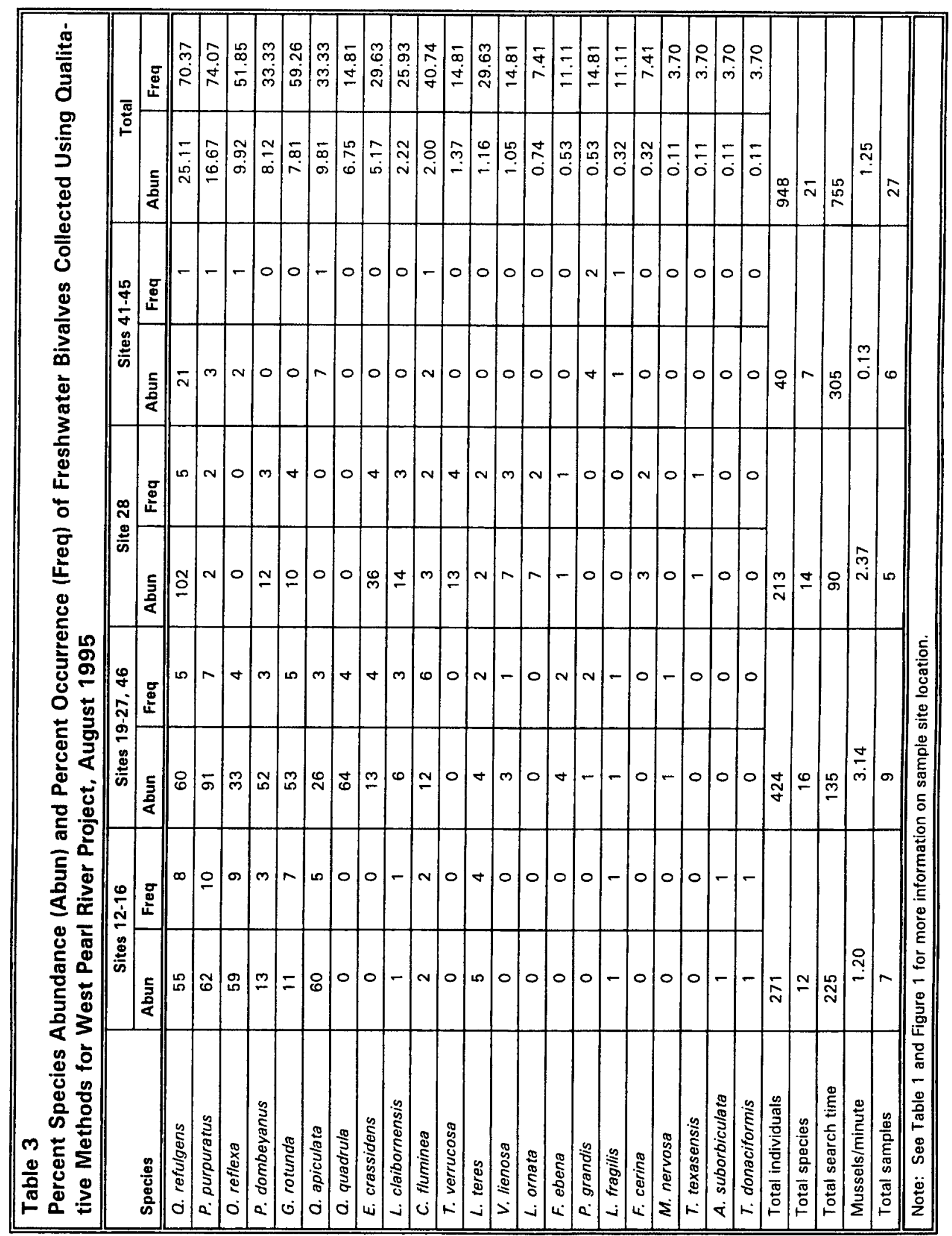




\begin{tabular}{|c|c|c|c|c|}
\hline \multicolumn{5}{|c|}{$\begin{array}{l}\text { Table } 4 \\
\text { Percent Abundance of Mussel Species Collected Using Quanti- } \\
\text { tative Methods in Bogue Chitto River Immediately Downriver of } \\
\text { Lateral Cutoff, West Pearl River Project, } 1995\end{array}$} \\
\hline Species & Subsite 1 & Subsite 2 & Subsite 3 & Total \\
\hline$Q$. refulgens & 84.62 & 34.02 & 83.93 & 54.82 \\
\hline L. claibomensis & 0.00 & 22.68 & 5.36 & 15.06 \\
\hline E. crassidens & 0.00 & 18.56 & 1.79 & 11.45 \\
\hline P. domboyanus & 0.00 & 8.25 & 1.79 & 5.42 \\
\hline$T$. verrucosa & 0.00 & 3.09 & 5.36 & 3.61 \\
\hline L. siliquoidea & 7.69 & 4.12 & 0.00 & 3.01 \\
\hline V. lienosa & 0.00 & 4.12 & 0.00 & 2.41 \\
\hline P. purpuratus & 0.00 & 2.06 & 0.00 & 1.20 \\
\hline F. ebena & 0.00 & 0.00 & 1.79 & 0.60 \\
\hline A. P. plicata & 0.00 & 1.03 & 0.00 & 0.60 \\
\hline Q. apiculata & 0.00 & 1.03 & 0.00 & 0.60 \\
\hline O. reflexa & 0.00 & 1.03 & 0.00 & 0.60 \\
\hline F. cerina & 7.69 & 0.00 & 0.00 & 0.60 \\
\hline Total species & 3 & 11 & 6 & 13 \\
\hline Total individuals & 13 & 97 & 56 & 166 \\
\hline Average density & 5.2 & 30.8 & 22.4 & 19.5 \\
\hline Standard error & 1.3 & 22.6 & 12.4 & 18.5 \\
\hline$\%$ ind $<30 \mathrm{~mm}$ & 23.07 & 1.30 & 5.36 & 4.79 \\
\hline$\%$ Species < $30 \mathrm{~mm}$ & 66.67 & 8.33 & 16.67 & 14.28 \\
\hline Species diversity & 0.83 & 1.12 & 0.80 & 1.00 \\
\hline Evenness & 0.54 & 1.81 & 0.68 & 1.54 \\
\hline Menhinick's Index & 0.59 & 0.75 & 0.43 & 0.53 \\
\hline
\end{tabular}

\section{Bogue Chitto River immediately downriver of Pearl River Canal}

Thirty quantitative samples were collected at three subsites on a shoal approximately $300 \mathrm{~m}$ downriver up the lateral canal (Tables 4 and 5). Mean density ranged from 5.2 to 30.8 with an overall mean of 19.5 (Standard error = 18.5). This fauna was dominated by $Q$. refulgens, which made up 55 percent of the fauna. Two species comprised 15 and 11 percent of the fauna, and five species were between 1 and 6 percent of the fauna. Evidence of recent 


\begin{tabular}{|c|c|c|c|c|}
\hline \multicolumn{5}{|c|}{$\begin{array}{l}\text { Table } 5 \\
\text { Percent Occurrence of Mussel Species Collected Using Quanti- } \\
\text { tative Methods in Bogue Chitto River Immediately Downriver of } \\
\text { the Pearl River Canal, West Pearl River Project, } 1995\end{array}$} \\
\hline Species & Subsite 1 & Subsite 2 & Subsite 3 & Total \\
\hline Q. refulgens & 70.0 & 90.0 & 100.0 & 86.7 \\
\hline E. crassidens & 0.0 & 50.0 & 10.0 & 20.0 \\
\hline$T$. verrucosa & 0.0 & 30.0 & 20.0 & 16.7 \\
\hline P. dombeyanus & 0.0 & 30.0 & 10.0 & 13.3 \\
\hline L. claibornensis & 0.0 & 20.0 & 10.0 & 10.0 \\
\hline L. siliquiodea & 10.0 & 20.0 & 0.0 & 10.0 \\
\hline V. lienosa & 0.0 & 30.0 & 0.0 & 10.0 \\
\hline P. purpuratus & 0.0 & 20.0 & 0.0 & 6.7 \\
\hline A. p. plicata & 0.0 & 10.0 & 0.0 & 3.3 \\
\hline F. ebena & 0.0 & 0.0 & 10.0 & 3.3 \\
\hline Q. apiculata & 0.0 & 10.0 & 0.0 & 3.3 \\
\hline O. reflexa & 0.0 & 10.0 & 0.0 & 3.3 \\
\hline F. cerina & 10.0 & 0.0 & 0.0 & 3.3 \\
\hline Total samples & 10 & 10 & 10 & 30 \\
\hline
\end{tabular}

recruitment was moderate. Overall, 4.8 percent of the individuals and 14 percent of the species had at least one species less than $30 \mathrm{~mm}$ total SL.

Using qualitative methods, the mussel collecting rate at this location was 2.4 individuals/minute. Fourteen species of bivalves were collected.

\section{Pearl River Canal (Sites 42-45)}

Only seven species and 40 mussels were collected in this reach. The collecting rate was extremely low; only 0.13 individuals were collected/minute. Quadrula refulgens comprised 52 percent of the fauna, and $Q$. apiculata made up 17 percent of the fauna.

\section{Lower Pearl River from just upriver of Highway 59 downriver to just below the Highway 90 Bridge (Sites 19-27, 46)}

A total of 424 mussels were collected at these sites. Sixteen species were taken, and overall rate was comparatively high, 3.14 individuals/minute. As 
with Sites $12-16$, this fauna was evenly distributed with no clear dominant.

The five most common species each comprised 12 to 21 percent of the fauna.

\section{Size Demography of Dominant Mussels}

Sufficient numbers of four species were collected to analyze size demography (Figure 2). All were collected in the Bogue Chitto River at Site 28.

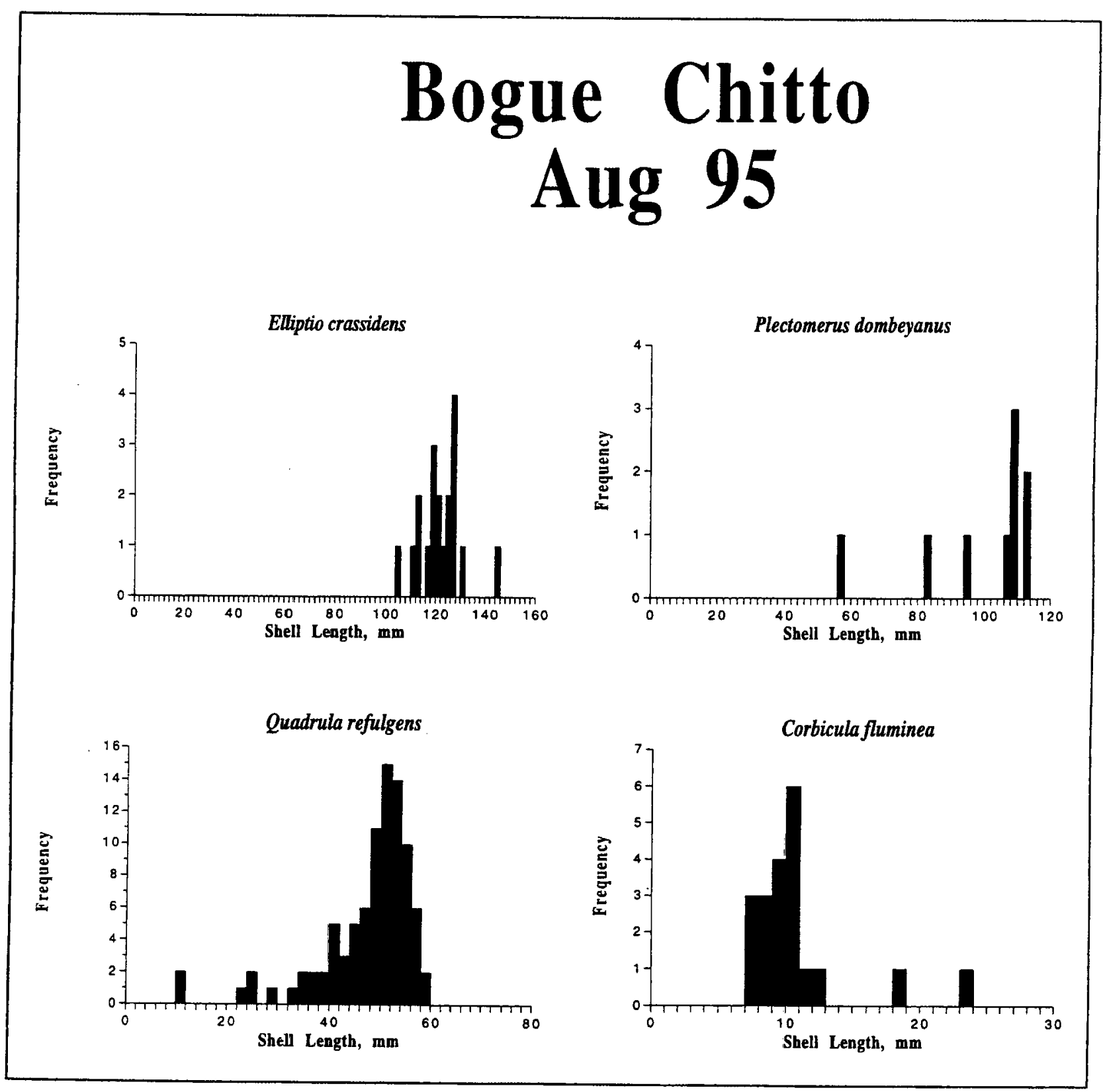

Figure 2. Size demography of dominant bivalves in project area, 1995 
All of the Elliptio crassidens that were collected were greater than $100 \mathrm{~mm}$ total SL. It is likely that two to three cohorts were present, although the small number of individuals makes discrimination among size classes difficult. There was no evidence of recent recruitment for this fairly common species.

The population of $C$. fluminea consisted of two cohorts. One centered at $10 \mathrm{~mm}$ was the result of recruitment early in 1995. Only two individuals were collected that were close to $20-\mathrm{mm}$ total SL. It is likely that these were recruited in the late summer or fall of 1994.

Only moderately sized to large Plectomerus dombeyanus were found at this location. There was no evidence of recent recruitment. Although small numbers make it difficult to interpret this population, it is likely that three cohorts were present.

Good evidence of recent recruitment was found for the abundant $Q$.

refulgens. One specimen was collected that was approximately $10 \mathrm{~mm}$ long, and the rest were greater than $20-\mathrm{mm}$ total SL. The dominant cohort was approximately $50 \mathrm{~mm}$ with mortality likely occurring at around $60-\mathrm{mm}$ total SL. A small cohort was likely present between 20 and $30 \mathrm{~mm}$, and another centered at slightly less than $40-\mathrm{mm}$ total SL. This species is doing well in this reach of the Bogue Chitto River. Overall densities were approximately 10 individuals/square meter, and evidence of recent recruitment was good.

\section{Potamilus inflatus}

Live specimens of $P$. inflatus, listed as threatened, were not found in the project area. Miller and Payne, in preparation, collected shells of $P$. inflatus in the Pearl River immediately upriver of the Pearl River Canal as part of the Walkiah Bluff project. In July 1995 two fresh dead $P$. inflatus were collected in the West Pearl River, St. Tammany Parish (George, Dickerson, and Reine 1996). The first was taken at the confluence of the Pearl River with the Pearl River Canal, and the second was taken under the I-59 Bridge. Based upon their position in the substratum, it appeared that both had died in situ and had not washed in from another location. Shells were in good condition, which indicates that they had been dead less than a year. No live $P$. inflatus were collected. It is likely that with additional effort, live specimens could be found. However, there is no doubt that live $P$. inflatus exist in this river reach. 


\section{Discussion}

\section{Bivalve Community}

Total bivalve species richness (unionids plus $C$. fluminea) in the project area (22) is similar to that found in most medium-sized to large rivers in the central United States. At a gravel bar in the lower Ohio River near Olmsted, IL, 23 species of mussels were identified. In a survey of a gravel bar in the lower Tennessee River, 4,768 individuals were collected and 23 species were identified (Miller, Payne, and Tippett 1992). In the east channel of the upper Mississippi River near Prairie du Chien, WI (RM 635), 30 species were identified (Miller et al. 1990). In a survey of other sites in the Pearl River for the Walkiah Bluff Project, Miller and Payne, in preparation, identified 29 species of bivalves. Obviously, more species are in this watershed, but not at the sites surveyed for this project.

Based on quantitative sampling at Site 28 in the Bogue Chitto River, the fauna was dominated by $Q$. refulgens ( 54.8 percent), with fewer numbers of $L$. claibornensis (15.1 percent), and E. crassidens (11.4 percent). Strong dominance by a single species caused the overall diversity to be fairly low, 1.0. Conversely, lack of a clear dominant species characterized a bed in the middle Ohio River near Cincinnati, $\mathrm{OH}$, where the most abundant species was Pleurobema cordatum and Quadrula p. pustulosa, which together comprised 39.9 percent of the assemblage (Miller and Payne 1993). At a bed in the lower Tennessee River, the fauna was dominated by $A$. p. plicata $(39.4$ percent) and Fusconaia ebena (39.4 percent) (Miller, Payne, and Tippit 1992).

In comparison with other large-river mussel beds, mean total unionid density at Site 28, which was 19.5 individuals/square meter, can be considered low. At an inshore and offshore site in the lower Tennessee River sampled in 1986 (32 quantitative samples were collected at each), total mussel density was 187.7 and 79.7 individuals/square meter, respectively (Way, Miller, and Payne 1989). In the middle Ohio River near Cincinnati, mussel density ranged from 4.4 to 52.4 individuals/square meter (Miller and Payne 1993). In a survey of the upper Mississippi River at locations between RMs 250 and 635, Miller et al. (1990) reported that total mussel density ranged from 5.2 to 333.2 individuals/square meter at 16 sites (10 quantitative samples were taken at each). At nearby sites in the Pearl River sampled for the Walkiah Bluff 
Project, total mean density ranged from less than 10 to more than 130 individuals/square meter, which can be considered moderate to high.

The number of individuals and species less than 30-mm total SL provides an estimate of recent recruitment. The overall percentage of individual native bivalves (excluding $C$. fluminea) less than $30-\mathrm{mm}$ total SL was 1.3 to 23.1 percent, which could be considered moderate. Occasionally, mussel beds are surveyed that exhibit evidence of strong recent recruitment. At a mussel bed in the lower Ohio River, a single cohort of $F$. ebena with an average shell length of $15.8 \mathrm{~mm}$ represented 71 percent of the population (Payne and Miller 1989). However, several years passed before strong recruitment for this species was noted. At sites in the Sunflower River, central Mississippi, virtually no evidence of recent recruitment was noted (Miller and Payne 1995).

The best mussel habitat in this project area was in the upper part of the Bogue Chitto River. Mussels were common, although in moderate to low densities between Highways 59 and 90 . Mussels were uncommon in the lateral canal. The project area could be characterized as having moderate species richness, density, and evidence of recent recruitment. Species diversity is usually low where only a single species (typically $Q$. refulgens) dominates in the project area. Commercially valuable species were virtually nonexistent in the project area.

The nonindigenous $C$. fluminea was present in low numbers at most sites in the project area. Another nonindigenous species, the zebra mussel, D. polymorpha, was not found in the project area, or at sites in the Pearl River and Holmes Bayou surveyed in 1995 (Miller and Payne 1995).

\section{Summary}

The West Pearl River between the end of the lateral canal and just downriver of the I-90 Bridge supports moderate- to high-density populations of mussels. The fauna consisted of common species; no unusual or endangered species were found. In the Bogue Chitto River (Site 28), moderately highdensity populations of mussels were located only along the right descending bank. If sediments from dredging have to be disposed downriver of the sill, the material should be directed toward the center of the channel or the left descending bank and away from the right bank to miss the mussels. In addition, sediments should be disposed as far downriver as possible to miss the existing mussel bed. The high current velocity in the Bogue Chitto River, approximately $1.0 \mathrm{ft} / \mathrm{sec}$ during the survey, should keep the sediments moving downriver.

It is likely that some mussels will be lost as a result of dredging and disposal of dredged material. Maintenance dredging will be done annually; therefore, mussels communities in these areas will not recover. Those areas 
affected by dredging, approximately 90 percent of the project area, will be unaffected. 


\section{References}

Burch, J. B. (1975). Freshwater Unionacean clams (Mollusca: Pelecypoda) of North America. Malacological Publications, Hamburg, MI.

Coker, R. E. (1919). "Fresh-water mussels and mussel industries of the United States," Bulletin of the United States Bureau of Fisheries, 13, 75-181.

Fuller, S. L. H. (1974). "Clams and mussels (Mollusca: Bivalvia)." Pollution ecology of freshwater invertebrates. C. W. Hart, Jr., and S. L. H. Fuller, ed., Academic Press, New York, 215-273.

George, S. G., Dickerson, D. D., and Reine, K. J. (1996). "Rediscovery of the inflated heelsplitter mussel, Potamilus inflatus, from the Pearl River Drainage," Journal of Freshwater Ecology 11(2), 245-246.

Isom, B. G., and Gooch, C. (1986). "Rationale and sampling design for freshwater mussels, Unionidae, in streams, large rivers, impoundments, and lakes." Rationale for sampling and interpretation of ecological data in the assessment of freshwater ecosystems. ASTM STP 894, B. G. Isom, ed., American Society for Testing and Materials, Philadelphia, PA, 46-59.

Kovalak, W. P., Dennis, S. D., and Bates, J. M. (1986). "Sampling effort required to find rare species of freshwater mussels." Rationale for sampling and interpretation of ecological data in the assessment of freshwater ecosystems. ASTM STP 894, B. G. Isom, ed., American Society for Testing and Materials, Philadelphia, PA, 34-45.

Ludwig, J. A., and Reynolds, J. F. (1988). Statistical ecology, a primer on methods and computing. John Wiley and Sons, New York.

Miller, A. C., and Nelson, D. (1983). "An instruction report on freshwater mussels," Instruction Report EL-83-2, U.S. Anny Engineer Waterways Experiment Station, Vicksburg, MS. 
Miller, A. C., and Payne, B. S. (1988). "The need for quantitative sampling to characterize size demography and density of freshwater mussel communities," Bulletin of the American Malacological Union, Inc. 6, 49-54.

Miller, A. C., and Payne, B. S. (1993). "Qualitative versus quantitative sampling to evaluate population and community characteristics at a largeriver mussel bed," The American Midland Naturalist 130, 133-145.

. (1995). "Analysis of freshwater mussels (Unionidae), Big Sunflower River maintenance project: 1993 studies," Technical Report EL-95-26, U.S. Army Engineer Waterways Experiment Station, Vicksburg, MS.

"Effects of water diversion on freshwater mussels in the Pearl River near Walkiah Bluff, Mississippi and Louisiana," Technical Report in preparation, U.S. Army Engineer Waterways Experiment Station, Vicksburg, MS.

Miller, A. C., Payne, B. S., Hombach, D. J., and Ragland, D. V. (1990). "An investigation of the physical effects of increased commercial navigation traffic on freshwater mussels in the upper Mississippi River: Phase I studies," Technical Report EL-90-3, U.S. Army Engineer Waterways Experiment Station, Vicksburg, MS.

Miller, A. C., Payne, B. S., Shafer, D. J., and Neill, L. T. (1993). "Techniques for monitoring freshwater bivalve communities and populations in large rivers." Proceedings of the conservation and management of freshwater mussels, October 12-14, 1992, St. Louis, MO, 147158.

Miller, A. C., Payne, B. S., and Tippit, R. (1992). "Characterization of a freshwater mussel (Unionidae) community immediately downriver of Kentucky Lock and Dam in the Tennessee River," Transactions of the Kentucky Academy of Sciences 53(3-4), 154-161.

Murray, H. D., and Leonard, A. B. (1962). Handbook of unionid mussels in Kansas. Museum of Natural History, University of Kansas, Lawrence, KS.

Parmalee, P. W. (1967). "The fresh-water mussels of Ilinois," Illinois State Museum Popular Science Series 8, 1-108.

Payne, B. S., and Miller, A. C. (1989). "Growth and survival of recent recruits to a population of Fusconaia ebena (Bivalvia: Unionidae) in the lower Ohio River," American Midland Naturalist 121, 99-104.

Shannon, C. E., and Weaver, W. (1949). The mathematical theory of communication. University of Illinois Press, Urbana IL. 
Sitwell, N. (1985). "The queen of gems--always stunning and now more cultured than ever," Smithsonian 1510, 41-50.

Starrett, W. C. (1971). "A survey of the mussels (Unionidae) of the Ilinois River: A polluted stream," Illinois Natural History Survey Bulletin 30(5), 266-403.

Sweaney, J. L., and Latendresse, J. R. (1982). "American freshwater natural pearls," Gemological Institute of America, Los Angeles, CA, 177-187.

U.S. Fish and Wildlife Service. (1994). "Endangered and threatened wildlife and plants," Federal Register, July 15, 1991, 50 CFR 17.11 and 17.12.

Way, C. M., Miller, A. C., and Payne, B. S. (1989). "The influence of physical factors on the distribution and abundance of freshwater mussels (Bivalvia: Unionidae) in the lower Tennessee River," The Nautilus 103, 96-98.

Williams, J. D., Warren, M. L., Jr., Cummings, K. S., Harris, J. L., and Neves, R. J. (1992). "Conservation status of freshwater mussels of the United States and Canada," Fisheries 18(9), 6-22. 


\section{Appendix A \\ Summary of Qualitative Data Collected for West Pearl River Project, 1995}

\begin{tabular}{|c|c|c|c|c|c|c|c|c|c|}
\hline \multirow[b]{2}{*}{ Species } & \multicolumn{7}{|c|}{ Site Number } & \multicolumn{2}{|c|}{ Grand Totals } \\
\hline & 12 & 13 & 14 & $\begin{array}{l}15 \\
\text { Shallow }\end{array}$ & $\begin{array}{l}15 \\
\text { Deep }\end{array}$ & $\begin{array}{l}16 \\
\text { Shallow }\end{array}$ & $\begin{array}{l}16 \\
\text { Deep }\end{array}$ & Abundance & Occurrence \\
\hline P. purpuratus & & & 26 & 18 & 6 & 4 & 8 & 22.88 & 71.43 \\
\hline Q. apiculata & & & 49 & 2 & 2 & & 7 & 22.14 & 57.14 \\
\hline O. reflexa & & & 11 & 16 & 18 & 1 & 13 & 21.77 & 71.43 \\
\hline Q. refulgens & 25 & & 11 & 4 & 23 & & 17 & 20.30 & 71.43 \\
\hline P. dombeyanus & & & 7 & 6 & & & & 4.80 & 28.57 \\
\hline G. rotunda & & & 5 & 3 & & 2 & 1 & 4.06 & 57.14 \\
\hline L. tores & & & 1 & 2 & & 2 & & 1.85 & 42.86 \\
\hline C. fluminea & & & & 1 & & 1 & & 0.74 & 28.57 \\
\hline L. tragilis & & & 1 & & & & & 0.37 & 14.29 \\
\hline$T$. donaciformis & & & & & 1 & & & 0.37 & 14.29 \\
\hline A. suborbiculata & & & & & & 1 & & 0.37 & 14.29 \\
\hline L. claibomensis & & & & & & 1 & & 0.37 & 14.29 \\
\hline Total individuals & 25 & 0 & 111 & 52 & 50 & 12 & 46 & 271 & \\
\hline Total species & 1 & 0 & 8 & 8 & 5 & 7 & 5 & 12 & \\
\hline Total search time & 30 & 30 & 15 & 45 & 30 & 45 & 30 & 225 & \\
\hline Mussels/minute & 0.8 & 0.0 & 7.4 & 3.5 & 3.3 & 0.8 & 3.1 & 1.2 & \\
\hline
\end{tabular}




\begin{tabular}{|c|c|c|c|c|c|c|c|}
\hline \multicolumn{8}{|c|}{$\begin{array}{l}\text { Table A2 } \\
\text { Numbers of Bivalves, Percent Abundance and Occurrence Col- } \\
\text { lected Using Qualitative Methods at Site 28, West Pearl River } \\
\text { Project, } 1995\end{array}$} \\
\hline \multirow[b]{2}{*}{ Species } & \multicolumn{5}{|c|}{ Sample Number } & \multicolumn{2}{|c|}{ Grand Totals } \\
\hline & 1 & 2 & 3 & 4 & 5 & Abundance & Occurrence \\
\hline Q. refulgens & 25 & 10 & 11 & 20 & 36 & 47.89 & 100.00 \\
\hline E. crassidens & 6 & 14 & 5 & 11 & & 16.90 & 80.00 \\
\hline L. claibornensis & 4 & 1 & 9 & & & 6.57 & 60.00 \\
\hline T. verrucosa & 7 & 1 & 3 & 2 & & 6.10 & 80.00 \\
\hline P. dombevanus & 4 & & 4 & & 4 & 5.63 & 60.00 \\
\hline G. rotunda & & 2 & 1 & 6 & 1 & 4.69 & 80.00 \\
\hline L. ornata & 1 & & & & 6 & 3.29 & 40.00 \\
\hline$v$. lienosa & 3 & 1 & 3 & & & 3.29 & 60.00 \\
\hline F. cerina & & 1 & 2 & & & 1.41 & 40.00 \\
\hline C. fluminea & & & 1 & 2 & & 1.41 & 40.00 \\
\hline L. teres & 1 & & 1 & & & 0.94 & 40.00 \\
\hline P. purpuratus & & & & 1 & 1 & 0.94 & 40.00 \\
\hline F. ebena & & 1 & & & & 0.47 & 20.00 \\
\hline T. texasensis & 1 & & & & & 0.47 & 20.00 \\
\hline Total individuals & 52 & 31 & 40 & 42 & 48 & 213 & \\
\hline Total species & 9 & 8 & 10 & 6 & 5 & 14 & \\
\hline Total time & 15 & 15 & 15 & 15 & 30 & 90 & \\
\hline Mussels/minute & 3.5 & 2.1 & 2.7 & 2.8 & 1.6 & 2.4 & \\
\hline
\end{tabular}




\begin{tabular}{|c|c|c|c|c|c|c|c|}
\hline \multicolumn{8}{|c|}{$\begin{array}{l}\text { Table A3 } \\
\text { Numbers of Bivalves, Percent Abundance and Occurrence Col- } \\
\text { lected Using Qualitative Methods, Pearl River Project Area, } 1995\end{array}$} \\
\hline \multirow[b]{2}{*}{ Species } & \multicolumn{5}{|c|}{ Site Number } & \multicolumn{2}{|c|}{ Grand Totals } \\
\hline & 41 & 42 & 43 & 44 & 45 & Abundance & Occurrence \\
\hline Q. refulgens & 21 & & & & & 52.50 & 20.0 \\
\hline Q. apiculata & 7 & & & & & 17.50 & 20.0 \\
\hline P. grandis & 1 & & & & 3 & 10.00 & 40.0 \\
\hline P. purpuratus & 3 & & & & & 7.50 & 20.0 \\
\hline O. reflexa & 2 & & & & & 5.00 & 20.0 \\
\hline C. fluminea & & & 2 & & & 5.00 & 20.0 \\
\hline L. fragilis & 1 & & & & & 2.50 & 20.0 \\
\hline Total individuals & 35 & 0 & 2 & 0 & 3 & 40 & \\
\hline Total species & 6 & 0 & 1 & 0 & 1 & 7 & \\
\hline Total time & 150 & 20 & 30 & 30 & 30 & 305 & \\
\hline Mussels/minute & 0.2 & 0.0 & 0.1 & 0.0 & 0.1 & 0.4 & \\
\hline
\end{tabular}




\begin{tabular}{|c|c|c|c|c|c|c|c|c|c|c|c|c|}
\hline \multicolumn{13}{|c|}{$\begin{array}{l}\text { Table A4 } \\
\text { Numbers of Bivalves, Percent Abundance } \\
\text { Methods, Pearl River Project Area, } 1995\end{array}$} \\
\hline \multirow[b]{2}{*}{ Species } & \multicolumn{10}{|c|}{ Site Number } & \multicolumn{2}{|c|}{ Grand Totals } \\
\hline & 19 & 20 & 21 & 22 & 23 & 24 & 25 & 26 & 27 & 46 & Abundance & Occurrence \\
\hline P. purpuratus & 3 & 35 & 1 & 36 & 2 & & & 1 & 13 & & 21.46 & 70.0 \\
\hline Q. quadrula & & 53 & & 2 & 1 & & & & 8 & & 15.09 & 40.0 \\
\hline Q. refulgens & & 16 & & 16 & 4 & & & & 24 & & 14.15 & 50.0 \\
\hline G. rotunda & 1 & 27 & & 11 & 2 & & & & 12 & & 12.50 & 50.0 \\
\hline P. dombeyanus & & 44 & & 6 & & & & & 2 & & 12.26 & 30.0 \\
\hline 0. reflexa & & 25 & & 1 & 1 & & & & 6 & & 7.78 & 40.0 \\
\hline Q. asperata & & 10 & & & 2 & & & & 14 & & 6.13 & 30.0 \\
\hline E. crassidens & & 2 & & 6 & 4 & & & & 1 & & 3.07 & 40.0 \\
\hline C. fluminea & 3 & 2 & & 2 & 1 & & & 1 & 3 & & 2.83 & 60.0 \\
\hline L. claibornensis & & 1 & & 3 & 2 & & & & & & 1.42 & 30.0 \\
\hline F. ebena & & 1 & & 3 & & & & & & & 0.94 & 20.0 \\
\hline L. teres & & 1 & & & 3 & & & & & & 0.94 & 20.0 \\
\hline V. lienosa & & 3 & & & & & & & & & 0.71 & 10.0 \\
\hline M. nervosa & & & & & & & & & 1 & & 0.24 & 10.0 \\
\hline P. grandis & & 1 & & & & & & & & & 0.24 & 20.0 \\
\hline L. fragilis & & & & & 1 & & & & & & 0.24 & 10.0 \\
\hline Total individuals & 7 & 221 & 1 & 86 & 23 & 0 & 0 & 2 & 84 & 0 & 424 & \\
\hline Total species & 3 & 14 & 1 & 10 & 11 & 0 & 0 & 2 & 10 & 0 & 16 & \\
\hline Total time & 15 & 15 & 15 & 15 & 15 & 15 & 15 & 15 & 15 & 45 & 135 & \\
\hline Mussels/minute & 0.5 & 14.7 & 0.1 & 5.7 & 1.5 & 0.0 & 0.0 & 0.1 & 5.6 & 0.0 & 3.1 & \\
\hline
\end{tabular}




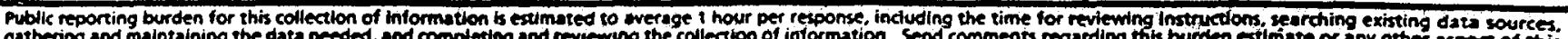
gathering and maintaining the data needed, and completing and reviewing the collection of intormation. Send comments regarding this burcen estimate or any other aspect of this Oevis Highway. Sulze 1204. Arlington, VA 222024302, and to the Otfice of Mansement and Budget, Paperwork Reduction Project (O704-0188). Washington, OC 20503.

\begin{tabular}{l|l|l} 
1. AGENCY USE ONLY (Leave blank) & $\begin{array}{l}\text { 2. REPORT DATE } \\
\text { September } 1997\end{array}$ & $\begin{array}{c}\text { 3. REPORT TYPE AND DATES COVERED } \\
\text { Final report }\end{array}$
\end{tabular}

4. TITLE AND SUBTITLE September 1997 5. FUNDING NUMBERS

A Survey of Freshwater Mussels in the West Pearl River,

Mississippi and Louisiana, 1995

6. AUTHOR(S)

Andrew C. Miller, Barry S. Payne

7. PERFORMING ORGANIZATION NAME(S) AND ADDRESS(ES)

U.S. Army Engineer Waterways Experiment Station

3909 Halls Ferry Road, Vicksburg, MS 39180-6199

8. PERFORMING ORGANHZATION REPORT NUMBER

Technical Report

EL-97-21

\section{SPONSORING/MONITORING AGENCY NAME(S) AND ADDRESS(ES)}

10. SPONSORING/MONITORING AGENCY REPORT NUMBER

U.S. Army Engineer District, Vicksburg

4155 Clay Street

Vicksburg, MS 39180-3435

\section{SUPPLEMENTARY NOTES}

Available from National Technical Information Service, 5285 Port Royal Road, Springfield, VA 22161.

12a. DISTRIBUTION/AVAILABILITY STATEMENT

Approved for public release; distribution is unlimited. 12b. DISTRIBUTION CODE

\section{ABSTRACT (Maximum 200 words)}

A survey to assess community characteristics, density, population demography of dominant species, and the presence of endangered species of mussels (Family: Unionidae) was conducted in selected reaches of the West Pearl River and lateral canal, near Slidell, LA, August-October 1995. The study was conducted to assess the environmental effects of maintenance dredging required for resumption of commercial navigation traffic.

Twenty-two species of bivalves, including the nonindigenous $C$. fluminea, were collected in the project area using quantitative and qualitative methods. The nonindigenous zebra mussel, Dreissena polymorpha, introduced into the Great Lakes in the late 1980s, and the threatened mussel, Potamilus inflatus, listed as endangered, were not found although they have been collected in the Pearl River upriver of the lateral canal. The bivalve community area can be characterized as species rich and diverse; typically, no single species dominated. Based on qualitative collections, the most abundant species were Quadrula refulgens and Potamilus purpuratus, which comprised 25 and 16.7 percent of the fauna. Eleven species each made up 1 to 10 percent of the fauna, and nine species were less than 1 percent of the collection.

(Continued)

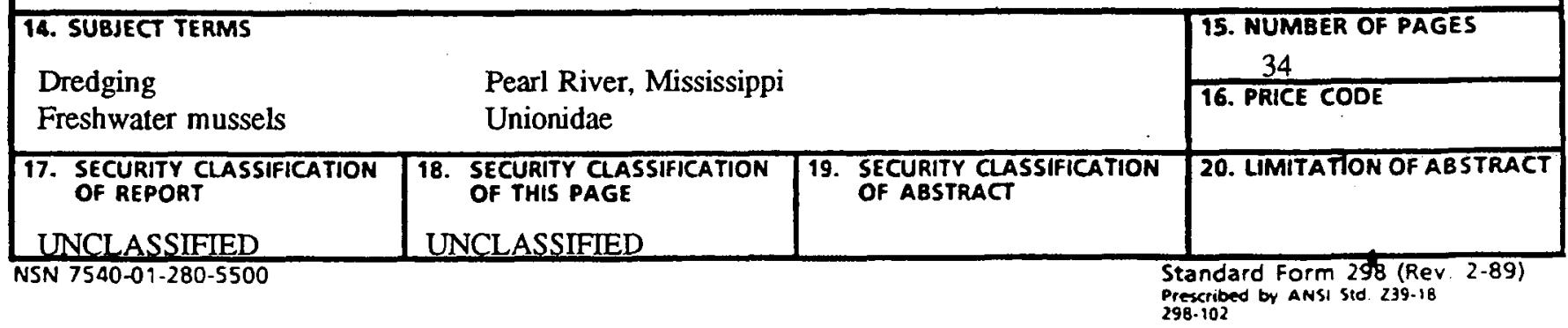


13. (Concluded).

Mean density of Unionidae at three sites in the Bogue Chitto River near the lateral canal ranged from 5.2 to 30.8 with an overall mean of 19.5 (Standard error $=18.5$ ). Overall, 4.8 percent of the individuals and 14 percent of the species had at least one species less than $30-\mathrm{mm}$ total shell length.

It is likely that some mussels will be lost by the effects of dredging and disposal of dredged material. It is difficult to predict just how much time will be required for dredged or disposal areas to recolonize. If the substratum is stable with moderate to low velocities, the area could colonize in less than 5 years. If conditions are of marginal value for mussels, it could take 10 or more years for a small assemblage to become established. 
Destroy this report when no longer needed. Do not return it to the originator. 